\title{
Determination Of The Age Of Blood Spots In Adults With Hemoglobin Levels Below Normal Based On The Natural Color System (Ncs) Standard Card
}

\author{
Oktafianna Malau ${ }^{\mathrm{a}}$, Adriansyah Lubis ${ }^{\mathrm{b}}$, Doaris Ingrid Marbun ${ }^{\mathrm{c}}$, Asan \\ Petrus $^{\mathrm{d}}$, Surjit singh ${ }^{\mathrm{e}}$ \\ amalauokta@gmail.com
}

Departement of Medicine Forensicand Medicolegal /RSUP H Adam Malik - Faculty of

Medicine, University of North Sumatra - Indonesia

\begin{abstract}
Background: A blood spot is a drop of blood originating from outside the body that hits a surface and undergoes a drying process and changes color over time. This color change process takes place between the 1 st hour to the 48th hour. After that time, the color of the blood spots will not change again. This process is caused by the oxidation of $\mathrm{HbO} 2$ molecules to methemoglobin, then methemoglobin will undergo a hemichrome process which results in decomposition and denaturation of blood spots.
\end{abstract}

Methods: An experimental study with a factorial time-series design that observed and assessed the color changes of blood spots in adult humans with normal hemoglobin levels based on the Natural Color System (NCS) color standard card, with a sample of all P3D students of the Faculty of Medicine, Malahayati University with hemoglobin levels below normal and meet the inclusion and exclusion criteria, carried out by taking two drops of the blood of the research subject from the tip of the middle finger, dripping on the ceramic and comparing the color changes that occur at the $1 \mathrm{st}$ hour, 2nd hour, 3rd hour, 4th hour , 5th hour, 6th hour, 7th hour, 8th hour, 10th hour, 12th hour, 24th hour, 48th hour, using the Natural Color Color Standard Card comparison tool System (NCS)

Result: The process of changing the color of the bloodstains occurred at the 1 st hour to the 6th hour, while at the 6th hour to the 48th hour, the color of the blood spots did not change color anymore. This is evidenced by the color code that appears at the 6th hour to the 48th hour, namely the NCS S $8502-\mathrm{R}$ color code as much as $87 \%$. This process is caused, because the oxyhemoglobin (HbO2) contained in blood spots with less hemoglobin levels below normal, so that the decomposition process or this oxidation process will take place more quickly. Initially, the $\mathrm{HbO} 2$ molecule will turn into methemoglobin, then methemoglobin will undergo a hemichrome process which results in the decomposition and denaturation of the blood spots.

Conclusion: The process of changing the color of the blood spots occurs at the 1st hour to the 6th hour, while at the 6th hour to the 48th hour, the color of the bloodspot does not change color anymore. This is evidenced by the color code that appears at the 6th hour to the 48th hour, namely the NCS S $8502-\mathrm{R}$ color code as much as $87 \%$.

Key Words: Hemoglobin Levels Below Normal, color change, Natural color system (NCS), age of blood spots 


\section{INTRODUCTION}

\section{Background}

A blood spot is a drop of blood originating from outside the body that hits a surface and undergoes a drying process and changes color over time. ${ }^{3,4}$ This color change process takes place between the 1st hour to the 48th hour. After that time, the color of the blood spots will not change again. This process is caused by the oxidation of $\mathrm{HbO} 2$ molecules to methemoglobin, then methemoglobin will undergo a hemichrome process which results in decomposition and denaturation of blood spots. $^{4,6}$

In crime cases, the forensic medicine department plays an important role in uncovering a murder case through the investigation processes carried out at the crime scene (TKP). In most cases of violent crimes, such as murder, assault, rape, etc., blood, semen, saliva, urine, hair and other body tissues may be found at the crime scene (TKP). These materials may come from the victim or perpetrator of the crime or from both, and can be used to help scientifically uncover the events of the crime. Materials like these are generally found in very small quantities, but the more careful and skilled an expert is, the more can be revealed. ${ }^{3}$

Stuart $\mathrm{H}$ James who was a member of the IABPA (International Association of Bloodstain Pattern Analysists) in 1999 had also conducted research on the interpretation of the color of blood spots found at crime scenes in America. But Stuart only examined the color of the bloodstains when the bloodstains didn't change anymore. ${ }^{19}$

In a 2011 study in Medan, Harianja also examined the age of blood spots based on color changes for 48 hours, using samples of blood spots on adult humans, with normal hemoglobin levels. During the observations, Harianja used a standard Natural Color System (NCS) color card to compare the color of the blood spots he observed. Based on the results of this study, it was concluded that the age of blood spots can be assessed based on the color changes that occur for 48 hours. $^{5}$

Fitra Afdani in 2014 in Pekan Baru, also examined the color change of blood spots in adult humans with below normal hemoglobin levels based on the Natural Color System (NCS) Color Standard Card. 1st to 6th hours and at 6th to 48th hours, 
the process of changing the color of the blood spots does not change color again or becomes stagnant.Berdasarkan latar belakang diatas, maka rumusan masalah pada penelitian ini adalah bagaimanakah penentuan umur bercak darah pada manusia dengan kadar hemoglobin dibawah normal berdasarkan kartu standar warna Natural Color System $(\mathrm{NCS})^{20}$

\section{BLOOD}

Blood is an essential component of living things, from primitive animals to humans. Under physiological conditions, blood is always in the blood vessels so that it can carry out its function as an oxygen carrier, the body's defense mechanism against infection, and the mechanism of hemostasis. 7 The amount in the body varies, depending on a person's weight. In adults, 1/13 of the body weight or approximately 4.5-5 liters is blood. Other factors that determine the amount of blood are age, occupation, state of the heart and blood vessels. ${ }^{10}$

\section{Hemoglobin}

Hemoglobin is part of erythrocytes which consists of heme and globin components. Heme is a combination of protoporphyrin with iron $(\mathrm{Fe})$, while globin is a protein consisting of two alpha chains and two beta chains. ${ }^{7}$

\section{Function of hemoglobin}

The function of hemoglobin is to transport $\mathrm{O} 2$ from the lungs and in the blood circulation to be carried to the tissues. The binding of hemoglobin with $\mathrm{O} 2$ is called oxyhemoglobin ( $\mathrm{HbO} 2)$, one gram of hemoglobin will combine with $1.34 \mathrm{ml}$ of $\mathrm{O} 2$, there are about 300 hemoglobin molecules contained in one erythrocyte cell. Besides $\mathrm{O} 2$, hemoglobin also carries carbon monoxide and with carbon monoxide forms carbon monoxyhemoglobin $(\mathrm{HbCO})$ bonds, also plays a role in the $\mathrm{pH}$ balance of the blood. Hemoglobin synthesis occurs during the erythropoiesis process, the maturation of red blood cells will affect the function of hemoglobin. ${ }^{7}$

\section{Increase and decrease in hemoglobin}

According to Bakta, 2006, The increase in hemoglobin levels depends on the duration of the reaction, also depending on the response of different individuals. Heavy physical work can also increase hemoglobin levels, this is due to the entry of a number of erythrocytes stored in the capillaries into the blood circulation or due to loss of plasma. ${ }^{8}$ 
Hemoglobin levels can be influenced by various factors, namely age, sex, pregnancy, menstruation, food intake, drinking tea or coffee habits (can reduce iron absorption), smoking habits and infectious diseases. There are several clinical problems that cause a decrease in hemoglobin levels such as anemia, cancer, kidney disease, excessive intravenous fluid administration and chronic disease or infection, as well as long-term administration of drugs such as antibiotics, aspirin, sulfonamides, primaquine, chloroquine.

\section{Gives Red Color To Blood}

Heme proteins function in the binding and transport of $\mathrm{O} 2$, as well as photosynthesis. The heme prosthetic group is a cyclic tetrapyrrole compound, whose extensive network consists of conjugated double bonds, which absorb light at the lower end of the visible spectrum, giving it a dark red color.

In blood spots with hemoglobin levels below normal, the oxidation process will quickly undergo, because there is less oxygen dissolved in the hemoglobin, which is then supported by various factors such as high temperature conditions, low humidity and exposure to sunlight which will affect the speed of the oxidation process. When seen with the naked eye, this process of color change will accelerate from initially red, to brownish red, then dark brown, and until finally the color of the blood spots is black. Therefore, the blood spots found at the crime scene are useful in the investigation process, especially in estimating the time of the crime. ${ }^{4}$ 1013,14

The most common bloodstains found at crime scenes are on the floor. This is because the drops of blood that fall to the floor follow the direction of the earth's gravity. In observing this bloodstain, there are several things that must be considered, one of which is the color of the floor. The color of the floor has an influence on the radiance of the color of the bloodstains. If the floor is dark, the color of the blood spots will be slightly darker than the original color, the opposite also happens on floors that have a light color. ${ }^{13}$,

Therefore, in describing the color of the bloodstains, investigators and forensic experts must consider these circumstances, so that the color of the bloodstains found at the crime scene can be interpreted properly. ${ }^{7,10}$ 


\section{RESEARCH METHOD}

This research is an experimental study with a factorial time-series design that observes and assesses the color changes of blood spots in adult humans with normal hemoglobin levels based on the Natural Color System (NCS) color standard card which was carried out in the period 10 September 2021-31 December 2021 in the Ministry of Environment. Forensic and Medicolegal Medicine, Faculty of Medicine, University of North Sumatra, Medan.

The population in this study were all P3D FK students of Malahayati University who had done a Medical Check Up and were willing to be the object of research. The research sample was all P3D FK students of Malahayati University with hemoglobin levels below normal and met the inclusion and exclusion criteria. With the Sampling Technique using the total sampling method, the research sample obtained from the data of P3D FK University Malahayati students who meet the inclusion criteria, namely: (1). All P3D FK students of Malahayati University who are willing to take part in the research. (2). All P3D FK students of Malahayati University were male with $\mathrm{Hb}<13 \mathrm{~g} / \mathrm{dl}$ and female with $\mathrm{Hb}<12 \mathrm{~g} / \mathrm{dl}$.

The tools and materials for this research are: (1). Sheets of the results of a thorough medical examination of research subjects. (2). Wall clock (3). Lancet (4). White ceramic size 30 x $30 \mathrm{~cm}$. (5). Room temperature gauge. (6). Natural Color System (NCS) color card Ingredients: 2 drops of research subject's blood.

As for how this research works, it starts with: (1). Data collection of research subjects was carried out including: name, age, gender (2). Checking the results of the health examination of the research subjects as a whole that meets the inclusion and exclusion criteria. (3). Taking the blood of the research subject from the tip of the middle finger by piercing the skin with a lancet from the tip of the middle finger as much as two drops by piercing the skin with the lancet, dripping on the ceramic and comparing the color changes that occur at the 1st hour, 2nd hour, and second hour. -3, 4th hour, 5th hour, 6th hour, 7th hour, 8th hour, 10th hour, 12th hour, 24th hour, 48th hour, using Natural Color System (NCS) color card. (4). Determine the color that occurs according to the time (hours) that has been determined based on the percentage of the number of colors that appear the most. (5). Room temperature during observations $25^{\circ} \mathrm{C}$. 
This research will be conducted after obtaining approval from the Ethics Committee of the Faculty of Medicine, University of North Sumatra, Medan with No: 1197/KEP/USU/2021.

\section{RESEARCH RESULTS}

Based on research conducted from October 23, 2021 to December 23, 2021, the results are obtained with the following details: 11 samples of the male gender group and 19 samples of the female sex group were obtained. Based on the results of the study, the percentage of the frequency of P3D students in the Hb group 9-9.9 was $6.6 \%$ (2 samples), the $\mathrm{Hb}$ group 10-10.9 was $16.7 \%$ (5 samples), the Hb group 11-11.9 was $36.7 \%$ (11 samples), while the $\mathrm{Hb}$ group 12-12.9 was $40 \%$ (12 samples)

Table 4.1 Percentage of the frequency of P3D students in the gender group

Gender Total Percentage

\begin{tabular}{ccc}
\hline Male & 11 & 36,6 \\
Female & 19 & 63,4 \\
\hline Total & $\mathbf{3 0}$ & $\mathbf{1 0 0}$ \\
\hline
\end{tabular}

Table 4.2 Percentage of the frequency of P3D students in the hemoglobin level group

\begin{tabular}{ccc}
\hline Hemoglobin levels & Total & Percentage \\
\hline $\mathbf{9 - 9 , 9}$ & 2 & 6,6 \\
$\mathbf{1 0 - 1 0 , 9}$ & 5 & 16,7 \\
$\mathbf{1 1 - 1 1 , 9}$ & 11 & 36,7 \\
$\mathbf{1 2 - 1 2 , 9}$ & 12 & 40 \\
Total & $\mathbf{3 0}$ & $\mathbf{1 0 0}$ \\
\hline
\end{tabular}

Table 4.3 Color-coded bloodstain percentage at 1st Hour

\begin{tabular}{ccc}
\hline Color code & Total & Percentage \\
\hline NCS S 1580-R & 25 & 83 \\
NCS S 2570-R & 5 & 17 \\
\hline Total & $\mathbf{3 0}$ & $\mathbf{1 0 0}$ \\
\hline
\end{tabular}


Table 4.4 Color-coded bloodstain percentage at the 2nd hour

\begin{tabular}{ccc}
\hline Color code & Total & Percentage \\
\hline NCS S 2570-R & 8 & 27 \\
NCS S 3560-R & 22 & 73 \\
Total & $\mathbf{3 0}$ & $\mathbf{1 0 0}$ \\
\hline
\end{tabular}

Table 4.5 Color-coded bloodstain percentage at 3 hours

\begin{tabular}{ccc}
\hline Color code & Total & Percentage \\
\hline NCS S 3560-R & 30 & 100 \\
\hline Total & $\mathbf{3 0}$ & $\mathbf{1 0 0}$ \\
\hline
\end{tabular}

Table 4.6 Color-coded bloodstain percentage at 4 hours

\begin{tabular}{ccc}
\hline Color code & Total & Percentage \\
\hline NCS S 4550-Y90R & 30 & 100 \\
\hline Total & $\mathbf{3 0}$ & $\mathbf{1 0 0}$
\end{tabular}

Table 4.7 Color-coded bloodstain percentage at 5 hours

\begin{tabular}{ccc}
\hline Color code & Total & Percentage \\
\hline NCS S 5040-R 10 & 5 & 17 \\
NCS S 8010-R10B & 25 & 83 \\
\hline Total & $\mathbf{3 0}$ & $\mathbf{1 0 0}$ \\
\hline
\end{tabular}

Table 4.8 Color-coded bloodstain percentage at 6 hours

\begin{tabular}{ccc}
\hline Color code & Total & Percentage \\
\hline NCS S 8010-R10B & 4 & 13 \\
NCS S 8502-R & 26 & 87 \\
Total & $\mathbf{3 0}$ & $\mathbf{1 0 0}$ \\
\hline
\end{tabular}


Table 4.9 Color-coded bloodstain percentage at 7 hours

\begin{tabular}{ccc}
\hline Color code & Total & Percentage \\
\hline NCS S 8010-R10B & 4 & 13 \\
NCS S 8502-R & 26 & 87 \\
Total & $\mathbf{3 0}$ & $\mathbf{1 0 0}$
\end{tabular}

Table 4.10 Color-coded bloodstain percentage at 8 hours

\begin{tabular}{ccc}
\hline Color code & Total & Percentage \\
\hline NCS S 8010-R10B & 4 & 13 \\
NCS S 8502-R & 26 & 87 \\
Total & $\mathbf{3 0}$ & $\mathbf{1 0 0}$ \\
\hline
\end{tabular}

Table 4.11 Color-coded bloodstain percentage at 9 hours

\begin{tabular}{ccc}
\hline Color code & Total & Percentage \\
\hline NCS S 8010-R10B & 4 & 13 \\
NCS S 8502-R & 26 & 87 \\
\hline Total & $\mathbf{3 0}$ & $\mathbf{1 0 0}$ \\
\hline
\end{tabular}

Table 4.12 Color-coded bloodstain percentage at 10 hours

\begin{tabular}{ccc}
\hline Color code & Total & Percentage \\
\hline NCS S 8010-R10B & 4 & 13 \\
NCS S 8502-R & 26 & 87 \\
\hline Total & $\mathbf{3 0}$ & $\mathbf{1 0 0}$
\end{tabular}

Table 4.13 Color-coded bloodstain percentage at 11 hours

\begin{tabular}{ccc}
\hline Color code & Total & Percentage \\
\hline NCS S 8010-R10B & 4 & 13 \\
NCS S 8502-R & 26 & 87 \\
\hline Total & $\mathbf{3 0}$ & $\mathbf{1 0 0}$ \\
\hline
\end{tabular}


Table 4.14 Color-coded bloodstain percentage at 12 hours

\begin{tabular}{ccc}
\hline Color code & Total & Percentage \\
\hline NCS S 8010-R10B & 4 & 13 \\
NCS S 8502-R & 26 & 87 \\
Total & $\mathbf{3 0}$ & $\mathbf{1 0 0}$ \\
\hline
\end{tabular}

Table 4.15 Color-coded bloodstain percentage at 24 hours

\begin{tabular}{ccc}
\hline Color code & Total & Percentage \\
\hline NCS S 8010-R10B & 4 & 13 \\
NCS S 8502-R & 26 & 87 \\
\hline Total & $\mathbf{3 0}$ & $\mathbf{1 0 0}$ \\
\hline
\end{tabular}

Table 4.16 Color-coded bloodstain percentage at 48 hours

\begin{tabular}{ccc}
\hline Color code & Total & Percentage \\
\hline NCS S 8010-R10B & 4 & 13 \\
NCS S 8502-R & 26 & 87 \\
Total & $\mathbf{3 0}$ & $\mathbf{1 0 0}$ \\
\hline
\end{tabular}

Picture 1. Changes in the color of blood spots at 1st hour to the 9 hours

\begin{tabular}{|c|c|c|c|c|c|c|c|c|c|c|c|c|c|c|c|}
\hline \multirow[t]{2}{*}{ No } & \multirow{2}{*}{$\begin{array}{l}\text { Hemoglobin } \\
(\mathrm{g} / \mathrm{dl})\end{array}$} & \multicolumn{14}{|c|}{ Jam Pengamatan } \\
\hline & & \multicolumn{2}{|c|}{ Jam ke-1 } & \multicolumn{2}{|c|}{ Jam ke-2 } & Jam ke-3 & \multirow[t]{2}{*}{ Jam ke-4 } & \multicolumn{2}{|c|}{ Jam ke-5 } & \multicolumn{2}{|c|}{ Jam ke-6 } & \multirow[t]{2}{*}{ Jam ke-7 } & Jamke-8 & \multicolumn{2}{|c|}{ Jam ke-9 } \\
\hline \multirow[t]{3}{*}{1} & \multirow[t]{3}{*}{$9-9,9$} & & & & & & & & & & & & & & \\
\hline & & $S 1580-R$ & SEOR & $\$ 2570 R$ & s35ser & S3560R & S 4550.Y9OR & s5900+100 & SODOGRIOE & 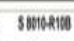 & SISPR & 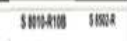 & 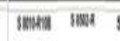 & simetion & sures \\
\hline & & $5(33,3)$ & $2(6,7)$ & $4(12)$ & $5(16,7)$ & $7(23,3)$ & $5(16,7)$ & $2(6,7)$ & $10(33,3)$ & $1(3,3)$ & $6(20)$ & $1(3,3) \quad 6(20)$ & $1(3,3) 5(16,7)$ & $1(3,3)$ & $6(20)$ \\
\hline \multirow[t]{3}{*}{2} & \multirow[t]{3}{*}{$10-10,9$} & & & & & & & & & & & & & & \\
\hline & & S1580R & Sarore & $\$ 2570,0$ & s3ear & $\$ 36002$ & SASSA YonP & Iseatian & Sorotorion & 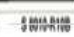 & SINON & SWWEITE IIEA & SWEAT SWER & 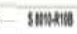 & 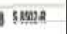 \\
\hline & & $5(33,3)$ & $1(3,3)$ & $1(3,3)$ & 4(1) & $5(16,7)$ & $10(33,3)$ & $1(3,3)$ & $2(6,7)$ & $1(3,3)$ & $5(16,7)$ & ) $1(3,3) 5(16,7)$ & $1(3,3) \underline{\underline{5}}(16,7)$ & 7) $1(3,3) 5$ & $5(16,7)$ \\
\hline \multirow[t]{3}{*}{3} & \multirow[t]{3}{*}{$11-11,9$} & & & & & & & & & & & & & & \\
\hline & & S1580-R & $\$ 2570-9$ & $\$ 2570 R$ & sissole & S3SER & S A5SO-Y90R & 3906R:B & S8010-R10B & 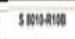 & sones & 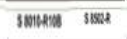 & SIMANIN SBSOR & SWOHAW & 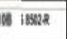 \\
\hline & & $13(43,3)$ & $1(3,3)$ & $2(6,7)$ & $8(27)$ & $14(47)$ & $930)$ & $1(3,3)$ & $10(33,3)$ & $1(3,3)$ & $7(21)$ & $1(3,3 \lcm{\underline{Z}}(21)$ & $1(3,3) \quad 7(21)$ & l) $1(3,3)$ & $27(21)$ \\
\hline \multirow[t]{3}{*}{4} & \multirow[t]{3}{*}{$12-12,9$} & & & & & & & & & & & & & & \\
\hline & & S1580:R & Szrin & S2570-R & s3sson & $\$ 3580 R$ & S ASSO-Y90R & SWERTOB & SMMERIII & Imores & SISOR & smotian sisses & 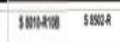 & Imexi: & S152A \\
\hline & & $2(6,7)$ & $1(3,3)$ & $1(3,3)$ & $5(16,7)$ & $4(\mathbb{1})$ & $6(20)$ & $1(3,3)$ & $3(10)$ & $1(3,3)$ & $8(27)$ & $1(3,3) \quad 8(27)$ & $1(3,3) \quad 8(27)$ & 7) $1(3,32$ & $8(27)$ \\
\hline \multicolumn{2}{|c|}{ Jumlah responden } & \multicolumn{2}{|c|}{$30(100)$} & \multicolumn{2}{|c|}{$30(100)$} & $30(100)$ & $30(100)$ & \multicolumn{2}{|c|}{$30(100)$} & \multicolumn{2}{|c|}{$30(100)$} & $30(100)$ & $30(100)$ & $30(1$ & 100) \\
\hline
\end{tabular}


Picture 2. Changes in the color of blood spots at 10 to 48 hours.

\begin{tabular}{|c|c|c|c|c|c|c|c|c|c|c|}
\hline \multirow[t]{2}{*}{ No } & \multirow{2}{*}{$\begin{array}{l}\text { Hemoglobin } \\
(\mathrm{g} / \mathrm{dl})\end{array}$} & \multicolumn{9}{|c|}{ Jam Pengamatan } \\
\hline & & \multicolumn{2}{|c|}{ Jam ke-10 } & \multicolumn{2}{|c|}{ Jam ke-11 } & Jam ke-12 & \multicolumn{2}{|c|}{ Jam ke-24 } & \multicolumn{2}{|c|}{ Jam ke-48 } \\
\hline \multirow[t]{3}{*}{5} & \multirow[t]{3}{*}{$9-9,9$} & & & \multirow[b]{2}{*}{ S 8010-R10B } & \multirow[b]{2}{*}{$S 8502-R$} & & & & & \\
\hline & & S 8010-R10B & S 8502-R & & & S 8010-R10B S S8502R & S 8010-R10B & $S 8502-R$ & S8010-R10B & S8502:R \\
\hline & & \multicolumn{2}{|c|}{$1(3,3) 6(20)$} & \multicolumn{2}{|c|}{$1(3,3) 6(20)$} & $1(3,3) 6(20)$ & \multicolumn{2}{|c|}{$1(3,3) 6(20)$} & \multicolumn{2}{|c|}{$1(3,3) 6(20)$} \\
\hline \multirow[t]{3}{*}{6} & \multirow[t]{3}{*}{$10-10,9$} & & & & & & & & \\
\hline & & S 8010-R10B & S 8502-R & S 8010-R10B & S 8502R & S 8010-R10B & S 8010-R10B & S 8502-R & S8010-R10B & SBSO2R \\
\hline & & \multicolumn{2}{|c|}{$1(3,3) 5(16,7)$} & \multicolumn{2}{|c|}{$1(3,3) 5(16,7)$} & $1(3,3) 5(16,7)$ & \multicolumn{2}{|c|}{$1(3,3) 5(16,7)$} & \multicolumn{2}{|c|}{$1(3,3) 5(16,7)$} \\
\hline \multirow[t]{3}{*}{7} & \multirow[t]{3}{*}{$11-11,9$} & & & & & & & & & \\
\hline & & S 8010-R10B & S 8502-R & S 8010-R10B & S8502R & S 8010-R10B $\quad S 8502-R$ & S 8010-R10B & S8502R & S 8010-R10B & S8502R \\
\hline & & $1(3,3$ & & $1(3,3)$ & & $1(3,3) 7(21)$ & $1(3,3)$ & (21) & $1(3,3)$ & $7(21)$ \\
\hline \multirow[t]{3}{*}{8} & \multirow[t]{3}{*}{$12-12,9$} & & & & & & & & & \\
\hline & & S 8010-R10B & $S 8502 \cdot R$ & S 8010-R10B & $S 8502 \cdot R$ & $S 8010-R 10 B \quad S 8502 \cdot R$ & S 8010-R10B & $\$ 8502 R$ & S8010-R10B & S B $8502 \cdot R$ \\
\hline & & $1(3$, & & $1(3,3)$ & & $1(3,3) 8(27)$ & $1(3,3)$ & & $1(3,3$ & $8(27)$ \\
\hline \multicolumn{2}{|c|}{ Jumlah responden } & \multicolumn{2}{|c|}{$30(100)$} & 30( & & $30(100)$ & 30( & 00) & 30( & $100)$ \\
\hline
\end{tabular}

\section{DISCUSSION}

Based on the table above, the results showed that the percentage with the dominant color code appearing at the 1st hour was NCS S $1580-\mathrm{R}$ as much as $83 \%$ (25 samples and NCS S 2570-R as much as 17\% (5 samples). blood at the 2nd hour is NCS S $3560-\mathrm{R}$ as much as $73 \%$ (22 samples) and NCS S $2570-\mathrm{R}$ as much as $27 \%$ (8 samples).The percentage of color coded blood spots at the 3rd hour is NCS S 3560-R as much 100\% (30 samples) The percentage of blood spot color coded at the 4th hour was NCS S 4550-Y90R as much as $100 \%$ (30 samples) The percentage of blood spot color coded at the 5th hour was NCS S 5040-R 10 as much as 17\% (5 samples) and $83 \%$ NCS S 8010-R (25 samples). The percentage of color coded blood spots at 6 to 48 hours was NCS S 8010-R10B as much as 13\% (4 samples) and NCS S 8502-R as much as $87 \%$ (26 samples).

The process of changing the color of the blood spots occurs at the 1st hour to the 6th hour, while at the 6th hour to the 48th hour, the color of the blood spot does not change color anymore. This is evidenced by the color code that appears at the 6th hour to the 48th hour, namely the NCS S $8502-\mathrm{R}$ color code as much as $87 \%$. This process is caused, because the oxyhemoglobin $(\mathrm{HbO} 2)$ contained in blood spots with less hemoglobin levels below normal, so that the decomposition process or this oxidation process will take place more quickly. Initially, the $\mathrm{HbO} 2$ molecule will turn into 
methemoglobin, then methemoglobin will undergo a hemichrome process which results in the decomposition and denaturation of the blood spots. In addition, there are also various other factors, which can affect the fast or slow process of the oxidation process, such as the state of temperature, humidity and exposure to sunlight. 4-10 but in this case, these conditions were not a control in this study.

The results of this study are in line with Fitra Afdani's research in Pekanbaru in 2014 where from the study it was found that the process of changing the color of the blood spots occurred at the 1st hour to the 6th hour, while at the 6th hour to the 48th hours, the process of discoloration of blood spots does not change color again or experience stagnation. This is evidenced by the color code that appears at the 6 th hour to the 48th hour, namely the NCS S 8502-R color code as much as $85.1 \%$.

\section{CONCLUSION}

From the results of research and discussion it was found that:

1. The percentage with the dominant color code appearing at the 1st hour is NCS S $1580-\mathrm{R}$ as much as $83 \%$,

2. The percentage with the dominant color code appearing at the 2 nd hour is NCS S $3560-\mathrm{R}$ as much as $73 \%$

3. The percentage with the dominant color code appearing at the 3rd hour is NCS S 4550-Y90R as much as $100 \%$

4. The percentage with the dominant color code appearing at the 4th hour is NCS S 5040-R10B as much as $100 \%$

5. The percentage with the dominant color code appearing at the 5th hour is NCS S $8010-\mathrm{R} 10 \mathrm{~B}$ as much as $83 \%$

6. The percentage with the dominant color code appearing at the 6th to 48th hours is NCS S $8502-\mathrm{R}$ as much as $87 \%$.

Thus, it can be concluded that the process of changing the color of the blood spots occurs at the 1st hour to the 6th hour, while at the 6th hour to the 48th hour, the process of changing the color of the blood spot does not change color again or becomes stagnant. This is evidenced by the color code that appears at the 6th hour to the 48th hour, namely the NCS S $8502-\mathrm{R}$ color code as much as $87 \%$. 


\section{REFERENCE}

1. Amir A. Sejarah Perkembangan Ilmu Kedokteran Forensik. Dalam: Rangkaian Ilmu Kedokteran Forensik. Edisi kedua. Bagian Ilmu Kedokteran FK-USU. Medan: 2005. h.2-5

2. Nandy A. Identification From Trace Substances and Their Other Evidential Values. In : Principles of Forensic Medicine. New Central Book Agency (P) Ltd. Calcutta - India. 1996.P. 110-130.

3. Camps F.E. Identification By Examination of The Blood and Identification by Trace Evidence. In : Gradwohl's Legal Medicine. A John Wright and Sons Ltd. Publication. Chicago. 1976. P. 147-190.

4. Parikh C.K. Forensic Examination of Biological Fluids, Stains and Other Materials. In : Parikh's Textbook of Medical Jurisprudence and Toxiology. Medicolegal Centre. Bombay - India. 1989.P. 606-656.

5. Wahid S. Bukti Fisikal. Dalam : Patologi Forensik. Dewan Bahasa dan Pustaka Kementrian Pendidikan Malaysia. Kuala Lumpur. 1993. H. 307-324.

6. https://repositori.usu.ac.id/bitstream/handle/123456789/41359/077113001.pdf?seq uence $=1$ \&isAllowed $=\mathrm{y}$

7. Hamdani N. Darah. Dalam : Ilmu Kedokteran Kehakiman. Edisi II. PT. Gramedia Pustaka Utama. Jakarta. 1992. H. 89-101.

8. Idries A. M. Pemeriksaan Darah. Dalam : Pedoman Ilmu Kedokteran Forensik. Edisi Pertama. Binarupa Aksara. Jakarta. 1992. H. 271- 283.

9. Chadha P.V. Bercak Darah. Catatan Kuliah Ilmu Forensik dan Toksikologi. Edisi V. Alih Bahasa Johan Hutauruk. Widya Medika. Jakarta. 1995. H.197-204.

10. Lichtman Marshall A, MD, et.all. Examination of The Blood, Williams Hematology, Seventh Edition, McGraw-Hill Medical Publishing Division, New York, 2006, p 1121.

11. Ganong WF. Cairan Tubuh Bersirkulasi, Fisiologi Kedokteran, Edisi 14, Penerbit Buku Kedokteran ECG, 1995, hal 486-97.

12. Hoffbrand AV, et all. Hemopoiesis, Kapita Selekta Hematologi, Penerbit Buku Kedokteran ECG, hal 1-24.

13. Jhon PG, et.all. Normal Hematologic System, Wintrobe's Clinical Hematology, Eleventh Edition, Volume 1, Lippincott Williams \& Wilkins, Philadelphia, 2003, p 169-249.

14. Bain J Barbara. A Beginner's Guide to Blood Cells, $2^{\text {nd }}$ Edition, Bllackwell Publishing Ltd, Australia, 2004, p 1-10.

15. Gonzales, Thomas A. Et.all. Examination of Blood, Legal Medicine Pathology and Toxicology, second Edition, Appleton-Century-Crofts, Inc, New York, 1954, p 62233.

16. Polson JC. Blood Stain, The Essential of Forensic Medicine, Second Edition Revised, Pergamon Press Ltd, Hungary, 1964, p219-28.

17. Parikh,C.K, Forensic Examination of Biological Fluids, Stains and Other Material, Parikh's Textbook of Medical Jurisprudence and Toxicology, Fifth Edition, CBS Publisher \& Distributors, New Delhi, India, 1992, p 606-16.

18. Budianto E. Metodologi Penelitian Kedokteran, Penerbit Buku Kedokteran ECG, Jakarta 2004.

19. Notoatmodjo S, Metodologi Penelitian Kesehatan, Penerbit Rineka Cipta, Jakarta 2005.

20. James, Stuart H ; Kish, Paul Erwin; Sutton, T. Paulette (2005). Principles of 
Bloodstain Pattern Analysis (3rd, illustrated, revised ed.). Taylor and Francis/CRCPressISBN0-8493-2014-3.

http://books.google.ca/books?id=aM6hNdjHRSgC. Retrieved 2009-01-30.

21. http://jik.fk.unri.ac.id/index.php/jik/article/download/42/39 